\title{
Effects of chelating agents on protein, oil, fatty acids, and minerals in soybean seed
}

\author{
Mudlagiri B. Goli ${ }^{1^{*}}$, Manju Pande ${ }^{1}$, Nacer Bellaloui ${ }^{2}$ \\ ${ }^{1}$ Natural Sciences and Environmental Health, Mississippi Valley State University, Itta Bena, USA; \\ ${ }^{*}$ Corresponding author: goli@mvsu.edu \\ ${ }^{2}$ Crop Genetics Research Unit, USDA-ARS, Stoneville, USA
}

Received 23 March 2012; revised 28 April 2012; accepted 15 May 2012

\begin{abstract}
Soybean seed is a major source of protein and oil for human diet. Since not much information is available on the effects of chelating agents on soybean seed composition constituents, the current study aimed to investigate the effects of various chelating agents on soybean [(Glycine $\max ($ L.) Merr.)] seed protein, oil, fatty acids, and mineral concentrations. Three chelating agent [citric acid (CA), disodium EDTA (DA), and salicylic acid (SA)] were applied separately or combined with ferrous $\left(\mathrm{Fe}^{2+}\right)$ ion (CA + Fe, EDTA + Fe, and $S A+F e$ ) to three-week-old soybean plants. After application, the plants were allowed to grow until harvest maturity under greenhouse conditions. The results showed that CA, DA, SA, and Fe resulted in an increase of oleic acid from $13.0 \%$ to $33.5 \%$. However, these treatments resulted in a decrease of linolenic acid from 17.8 to $31.0 \%$. The treatments with CA and SA applications increased protein from $2.9 \%$ to $3.4 \%$. The treatments $\mathrm{DA}+\mathrm{Fe}$ and $\mathrm{SA}+\mathrm{Fe}$ resulted in an increase in oil from $6.8 \%$ to $7.9 \%$. Seed macroand micro-elements were also altered. The results indicated that the CA, SA, DA, and Fe treatments can alter seed protein, oil, fatty acids, and mineral concentrations. Further studies are needed for conclusive results.
\end{abstract}

Keywords: Chelating Agents; Fatty Acids; Minerals; Oil; Protein; Soybean Seed Composition

\section{INTRODUCTION}

Soybean seeds are a major source of protein and oil [1], carbohydrates, minerals, and secondary metabolites

\#Mention of trade names or commercial products in this publication is solely for the purpose of providing specific information and does not imply recommendation or endorsement by the US Department of Agriculture. such as lignin and isoflavones [2-5]. The quality of the soybean seed and the flavor and shelf-life of the oil produced are determined by protein, oil, and fatty acid content and quality. The five main fatty acids present in soybean seed are palmitic (16:0), stearic (18:0), oleic (18:1), linoleic (18:2), and linolenic (18:3) [6]. The higher linoleic and linolenic acids were reported to lower the shelf-life of the oil due to oxidation of polyunsaturated acids $[7,8]$. Hence, the soybean industry prefers soybean with lower percentages of linoleic and linolenic acids, and higher percentage of oleic acid. Earlier reports have studied the growth response of plants in a nutrient solution containing chelating agents with ferric $\left(\mathrm{Fe}^{3+}\right)$ ions. In this experiment, soybeans were exposed to different dosages of metal ion and chelating agents. In the absence of iron $(\mathrm{Fe})$ or when only the chelating agent was present, the plant showed chlorosis. Spraying iron sulfate $\left(\mathrm{FeSO}_{4}\right)$ solution on the plants resulted in plants' recovery from the chlorosis [9]. Iron movement in the growth medium is reported to be dependent on the chelating agents, $\mathrm{pH}$, and exposure time to ligand [10]. In an experiment on monocotyledonous species, where $\mathrm{NaFe}$ EDDHA chelate $[\mathrm{Fe}$ ethylenediamine di (O-hydroxyphenylacetate)] was used, it was reported that the root system was better able to absorb ferrous $\mathrm{Fe}^{2+}$ ion than the ferric $\mathrm{Fe}^{3+}$ ion [11].

Although using synthetic chelating agents helped to understand plant nutrition, the micronutrient carrier from soil to plants [12] and the uptake of iron-chelating agents by plants are still not fully understood. Application of micronutrients is important for soybean yield and seed quality, especially in nutrient-deficient soil [13-21]. Iron is critical for chlorophyll formation, photosynthesis, respiration [21]. Most soils contain abundant levels of iron. However, at higher $\mathrm{pH}$ or in poor drainage, iron may not be available to plants, leading to iron deficiency $[11,12$, 14,15,18-20]. Combinations of chelating agents can increase iron availability $[9,11,12]$, and thus may improve seed constituents. Studies have reported that the use of citric and oxalic acid on lemongrass resulted in better 
growth compared to the use of EDTA [22]. The objective of this study was to investigate the effects of applying chelating agents citric acid, salicylic acid, and the synthetic agent Disodium EDTA, alone and in combination with ferrous ion on soybean seed protein, oil, fatty acids, and minerals. To our knowledge, this is the first study to investigate the effects of chelating agents on seed protein, oil, and fatty acids in soybean.

Our hypothesis was that the plants may absorb the naturally occurring low binding $\left(10^{3-16}\right)$ citric and Salicylic acids as chelating agents for metal ions over EDTA, which have higher binding constants $\left(10^{10-25}\right)$ to different metal ions [23] for transporting iron and other micro- and macro-nutrients into the plants. Our hypothesis was based on the fact that metal ions (M) bind differently to different chelating agents (called also ligand, L), and form metal-ligand complexes (ML). The higher amount of ML than L or M in the solution implies that the ligand has a high binding constant with the metal $\mathrm{M}$. Details on Stability Constants $\left(\log \mathrm{K}_{1}\right)$ of various metal chelates that defines this complex chemistry are reported elsewhere [23].

\section{MATERIALS AND METHODS}

\subsection{Treatment and Experimental Design}

A greenhouse experiment was carried out at Mississippi Valley State University. Seeds of glyphosate-resistant Pioneer 95Y70 cultivar were planted in late April 2010, and seeds were collected at harvest maturity by early October 2010. Soil treatments were: Control, $\mathrm{FeCl}_{2}$ $(\mathrm{Fe})$, citric acid (CA), disodium EDTA (DA), salicylic acid (SA), $\mathrm{CA}+\mathrm{Fe}, \mathrm{DA}+\mathrm{Fe}$, and $\mathrm{SA}+\mathrm{Fe}$. Each set of treatment consisted of four pots. Four soybean seeds were planted in each pot. After three weeks of plant growth, the pots were treated with the appropriate chelating compound. To prepare the solution, $2.4 \mathrm{mmol}$ of the chelating compound were dissolved in $2000 \mathrm{~mL}$ of deionized water (DI); then $250 \mathrm{~mL}$ of the solution were used per pot. This equates to $0.30 \mathrm{mmol}$ of sample dissolved in $250 \mathrm{~mL}$ of water per pot. The chemical application was applied twice within a week at vegetative stage. The soil moisture levels of pots in the greenhouse were regularly monitored using soil water potential sensors. The pots were watered twice a week. The plants were grown under greenhouse conditions of natural light and temperature. Temperature during the soybean growing season ranged from $21^{\circ} \mathrm{C}$ to $40^{\circ} \mathrm{C}$.

\subsection{Harvesting}

Soybean seeds were collected at harvest maturity (R8) for seed protein, oil and fatty acid, and mineral analysis.

\subsection{Seed Protein, Oil, and Fatty Acid Analyses}

Seeds from each soybean pot were sampled and analyzed for protein, oil and fatty acids using near-infrared (NIR) reflectance diode array feed analyzer (Perten, Spring Field, IL, USA) [24,25]. Calibration curves have been regularly updated for unique samples according to AOAC methods [26,27].

\subsection{Seed Mineral and Soil Analyses}

Elemental analysis of the seeds and soil samples was carried out by Soil, Water, Plant and Animal Tissue Analysis Laboratory, University of Georgia, Athens, GA, USA [28].

\subsection{Experimental Design and Statistical Analyses}

The experiment was a randomized complete block design. Four replicates were used. Analysis of variance was conducted using Proc GLM in SAS [29], with level of significance of $p \leq 0.05$.

\section{RESULTS}

\subsection{Seed Protein, Oil, and Fatty Acids}

The citric acid (CA) and salicylic acid (SA) applications increased seed protein percentage by $2.9 \%$ and $3.4 \%$, respectively (Table 1). Conversely, disodium EDTA (DA) $+\mathrm{Fe}$, and $\mathrm{SA}+\mathrm{Fe}$ applications decreased the protein percentage by $4.1 \%$ and $4.4 \%$, respectively. The DA $+\mathrm{Fe}$, and $\mathrm{SA}+\mathrm{Fe}$ applications increased oil by $7.1 \%$ and $8.2 \%$, respectively. The Fe, CA, DA, and SA applications decreased seed palmitic acid from $8.7 \%$ to $16.7 \%$, with $\mathrm{SA}$ having the greatest effect. The $\mathrm{CA}+\mathrm{Fe}$, and $\mathrm{DA}+\mathrm{Fe}$ applications increased palmitic acid by $8.7 \%$ and $10.3 \%$, respectively. The application of $\mathrm{CA}, \mathrm{CA}+\mathrm{Fe}, \mathrm{DA}+\mathrm{Fe}$, and $\mathrm{SA}+\mathrm{Fe}$ increased stearic acid from $4.7 \%$ to $9.3 \%$, with $\mathrm{CA}$ and $\mathrm{SA}+\mathrm{Fe}$ applications having the greatest increase of $9.3 \%$. The Fe, CA, DA, SA and SA + Fe applications increased oleic acid by $13.0 \%$ to $33.0 \%$, with $\mathrm{CA}$ having the greatest effect. The $\mathrm{CA}+\mathrm{Fe}$ and $\mathrm{DA}+\mathrm{Fe}$ applications decreased oleic acid by $13.3 \%$ and $17.0 \%$, respectively. The DA and SA applications increased linoleic acid by $4.0 \%$ and $4.6 \%$, respectively. The SA $+\mathrm{Fe}$ application decreased linoleic by $3.1 \%$. The Fe, CA, DA and SA applications decreased linolenic acid by $17.7 \%$ to $31.3 \%$, with SA having the greatest effect.

In summary, the treatments with $\mathrm{FeCl}_{2}, \mathrm{CA}, \mathrm{DA}, \mathrm{SA}$, $\mathrm{CA}+\mathrm{FeCl}_{2}$, $\mathrm{DA}+\mathrm{FeCl}_{2}$, and $\mathrm{SA}+\mathrm{FeCl}_{2}$ have different effects on the soybean seed protein, oil, palmitic, stearic, linoleic, and linolenic acid \%. Application of CA increased oleic acid by $33.0 \%$, but decreased linolenic acid percentage by $17.7 \%$. Similar observation for SA appli- 
Table 1. Mean values of protein, oil, and fatty acid percentage (\%) as affected by treatments: $\mathrm{C}=$ control, $\mathrm{Fe}=\mathrm{FeCl}, \mathrm{CA}=$ citric acid, $\mathrm{DA}=$ disodium EDTA, $\mathrm{SA}=$ salicylic acid, $\mathrm{CA}+\mathrm{Fe}=\mathrm{Citric}$ acid $+\mathrm{FeCl}_{2}, \mathrm{DA}+\mathrm{Fe}=$ Disodium $\mathrm{EDTA}+\mathrm{FeCl}_{2}$, and $\mathrm{SA}+\mathrm{Fe}=$ salicylic acid $+\mathrm{FeCl}_{2}$.

\begin{tabular}{|c|c|c|c|c|c|c|c|}
\hline Treatments & Protein & Oil & $\begin{array}{l}\text { Palmitic } \\
(\mathrm{C} 16: 0)\end{array}$ & $\begin{array}{c}\text { Stearic } \\
(\mathrm{C} 18: 0)\end{array}$ & $\begin{array}{c}\text { Oleic } \\
(\mathrm{C} 18: 1)\end{array}$ & $\begin{array}{l}\text { Linoleic } \\
\text { (C18:2) }\end{array}$ & $\begin{array}{c}\text { Linolenic } \\
(\mathrm{C} 18: 2)\end{array}$ \\
\hline $\mathrm{C}$ & $41.2 \mathrm{~cd}$ & $18.4 \mathrm{~cd}$ & $12.6 \mathrm{~b}$ & $4.3 \mathrm{~d}$ & $18.75 \mathrm{c}$ & $54.4 \mathrm{cb}$ & $9.6 \mathrm{ab}$ \\
\hline $\mathrm{CA}$ & $42.4 \mathrm{ab}(+2.9 \%)$ & $19.0 \mathrm{bcd}$ & $10.8 \mathrm{~d}(-14.3 \%)$ & $4.7 \mathrm{a}(+9.3 \%)$ & $25.0 \mathrm{~b}(+33.0 \%)$ & $53.2 \mathrm{~cd}$ & $7.9 \mathrm{c}(-17.7 \%)$ \\
\hline DA & 42.1abc & $19.0 \mathrm{bcd}$ & $11.0 \mathrm{~cd}(-12.7 \%)$ & $4.3 \mathrm{~d}$ & $21.4 \mathrm{~b}(+13.8 \%)$ & $56.6 \mathrm{a}(+4.0 \%)$ & $6.9 \mathrm{~d}(-28.1 \%)$ \\
\hline $\mathrm{CA}+\mathrm{Fe}$ & $40.9 \mathrm{~d}$ & $18.3 \mathrm{~cd}$ & $13.7 \mathrm{a}(+8.7 \%)$ & $4.5 \mathrm{~b}(+4.7 \%)$ & $16.3 \mathrm{~d}(-13.3 \%)$ & $55.8 \mathrm{ab}$ & $9.8 \mathrm{a}$ \\
\hline $\mathrm{DA}+\mathrm{Fe}$ & 39.5 e $(-4.1 \%)$ & $19.7 \mathrm{ab}(+7.1 \%)$ & $13.9 \mathrm{a}(+10.3 \%)$ & $4.5 \mathrm{bc}(+4.7 \%)$ & $15.6 \mathrm{~d}(-17.0 \%)$ & $55.5 \mathrm{ab}$ & $10.5 \mathrm{a}$ \\
\hline $\mathrm{SA}+\mathrm{Fe}$ & $39.4 \mathrm{e}(-4.4 \%)$ & $19.9 \mathrm{a}(+8.2 \%)$ & $12.5 \mathrm{~b}$ & $4.7 \mathrm{a}(+9.3 \%)$ & $22.9 \mathrm{~b}(22.8 \%)$ & $52.7 \mathrm{~d}(-3.1 \%)$ & $8.9 b$ \\
\hline
\end{tabular}

* Means given within a column with the same letter are not significantly different at $\mathrm{p} \leq 0.05$. Four replicates were used. The numbers in the brackets with $\%$ are increase $(+)$ or decrease $(-)$ from the control for a given seed composition constituents.

cation where oleic acid increased by $15.4 \%$ and linolenic acid decreased by $31.3 \%$. The CA and SA applications decreased palmitic acid by $14.3 \%$ and $16.7 \%$, respectively. Applications of CA and SA increased protein percentage by $2.9 \%$ and $3.4 \%$, respectively.

\subsection{Ratios of $A_{1} / A_{2}$}

Table 2 shows the effect of chemical applications on the unsaturated fatty acids linoleic and linolenic compared with palmitic, stearic, and oleic acids. That is, $A_{1}=$ linoleic + linolenic acids, and $\mathrm{A}_{2}=$ palmitic, stearic, and oleic acids. For control, the ratio was 1.79. Higher ratio means higher $\%$ of linoleic and linolenic acids were produced. For Fe, CA, DA, SA, and SA + Fe applications, the ratios ranged from 1.51 to 1.73 . Application of CA had the lowest ratio (1.51) followed by SA + Fe application (1.53). Lower ratios means lower $\%$ of linoleic and linoleic acids and higher percentage of oleic acid produced. Applications of $\mathrm{FeCl}_{2}, \mathrm{CA}, \mathrm{SA}, \mathrm{DA}$, and $\mathrm{SA}+$ $\mathrm{FeCl}_{2}$ increased oleic acid.

\subsection{Macro and Micro-Elements in Seed}

Chemical treatments had varying degrees of influence on the composition of macro-elements in the seed. Application of $\mathrm{FeCl}_{2}$ increased calcium by $25 \%, \mathrm{Mg}$ by $7.0 \%$, and $\mathrm{N}$ by $5.5 \%$ (Table 3 ). The CA application increased $\mathrm{N}$ by $6.4 \%$, and decreased $\mathrm{P}$ by $10.3 \%$. The SA application increased $\mathrm{N}$ by $7.4 \%$ and decreased $\mathrm{S}$ by $12.5 \%$. The $\mathrm{FeCl}_{2}$ application increased $\mathrm{B}$ by $16.0 \%, \mathrm{Cu}$ by $7.0 \%, \mathrm{Fe}$ by $14.0 \%$, and $\mathrm{Zn}$ by $14.0 \%$. The CA application increased $\mathrm{B}$ by $11.0 \%, \mathrm{Cu}$ by $17.0 \%$, Fe by $31.0 \%$, Na by $30.0 \%$, and $\mathrm{Zn}$ by $15.0 \%$. The SA application increased $\mathrm{B}$ by $11.0 \%, \mathrm{Cu}$ by $24.5 \%$ and decreased $\mathrm{Fe}$ by $10.4 \%$. The DA application increased Cu by $50.0 \%$, Mo by $57.0 \%$ and $\mathrm{Zn}$ by $28.0 \%$ (Table 3 ).

\subsection{Macro- and Micro-Elements in Soil}

The percentage $(\%)$ of elements in soil were $\mathrm{N}=$ $2.11 \%, \mathrm{~K}=0.35 \%, \mathrm{Ca}=3.3 \%, \mathrm{Mg}=0.21 \%, \mathrm{~S}=0.17 \%$, and $\mathrm{P}=0.02 \%$ (Table 4). The micro-elements concentration $(\mathrm{mg} / \mathrm{kg})$ in soil were $\mathrm{Mn}=84.0, \mathrm{Fe}=65.0, \mathrm{~B}=0.6$, $\mathrm{Zn}=6.5, \mathrm{Na}=81.0, \mathrm{Cu}=0.5$, and $\mathrm{Mo}=0.1$ (Table 4).

\subsection{Stability Constants of Chelating Agents, CA, SA and DA}

Table 5 shows the binding constants of chelating agents used in this study. A strong metal ions-EDTA complex is made, and this is due to the EDTA-binding constant, $10^{10-25}$, which varies depending on the type of metal ions. Citric $\left(10^{2.8-11.85}\right)$ and salicylic acids $\left(10^{2.7-16.35}\right)$ weakly bind with the metal ions. Structures of EDTA, salicylic acid, and citric acid and their binding to metal ion are presented in Figure 1, and the chemical structure of fatty acids are shown in Figure 2. The chemical structures in Figure 2 were drawn using a ChemSkecth program provided by a chemistry development software program (freeware) [30].

\section{DISCUSSION}

Research is scarce on the influence of the application of chelating agents to soil on soybean seed protein, oil, fatty acid, and mineral contents. In an earlier study on soybean plants grown in nutrient solution, it was reported that the chelating agent was absorbed by plants only when the chelating agent concentration was higher than the metal ion concentration [9]. It was also concluded that chelating agents applied in the absence of iron are absorbed by the plant and bound to the iron in the plant, causing chlorosis [9]. Spraying such plants with $\mathrm{FeSO}_{4}$ resulted in rapid recovery and chlorosis elimination [9]. It was also reported that in nutrient solutions of chelating 


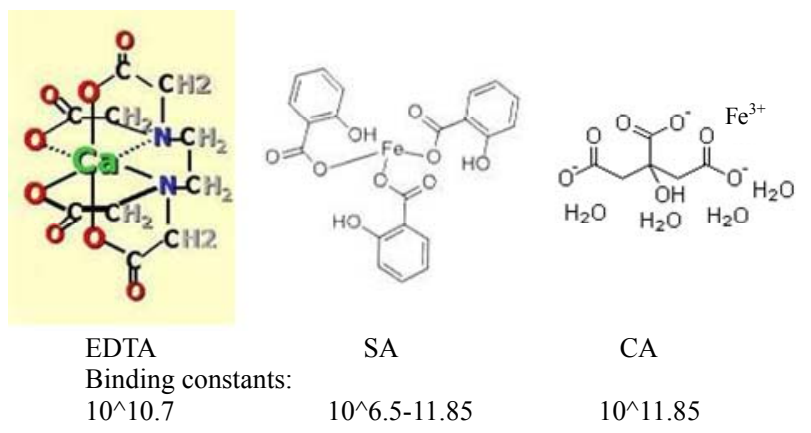

Figure 1. Chemical structures of chelating agents and their binding constants [23].

Palmitic acid (16:0)<smiles>CCCCCCCCCCCCCCCC(=O)O</smiles>

Stearic acid (18:0)<smiles>CCCCCCCCCCCCCCCCCC(=O)O</smiles>

Oleic acid (18:1)<smiles>CCCCCCCC/C=C\CCCCCCCC(=O)O</smiles>

Linoleic acid (18:2)<smiles>CCCCC/C=C\C/C=C\CCCCCCCC(=O)O</smiles>

Liniolenic acid (18:3)<smiles>CC/C=C\C/C=C\C/C=C\CCCCCCCC(=O)O</smiles>

Figure 2. Structures of five fatty acids [30]. agent and ferric ion, the roots of kidney beans and soybeans seeds competed with the chelating agents for the ferric ion, and the competitive effect was overcome by adding more metal ion into the nutrient solution [31]. It was shown in radish sprouts grown in a growth medium that Ethylenediaminedisuccinic acid (EDDS) and hydroxy-iminodisuccinic acid (HIDS) produced the highest apparent mobility of iron from the bottom layer of the medium (initially $10^{-4} \mathrm{M} \mathrm{Fe}(\mathrm{III})$ ) to the upper layer (no iron), followed by glutamatediacetic acid (GLDA), ethylenediaminetetraacetic acid (EDTA), implying that the HIDS is an effective carrier of metal ion from the solution than EDTA. The mobility of the ion depended upon the chelating agent, $\mathrm{pH}$, and exposure time [10]. Their observation was that the plant may be converting ferric ion into ferrous before absorption [11]. Although using synthetic chelating agents may help us understand metal ion uptake by plants, their usefulness as a micronutrient carrier is still debatable [12].

In our study, ferrous ion applications altered the composition of fatty acids and minerals in seeds. For example, the chelating agents, especially CA and SA, had major effects on seed protein, fatty acids, and mineral composition. The treatments $\mathrm{DA}+\mathrm{Fe}$ and $\mathrm{SA}+\mathrm{Fe}$ resulted in an increase in oil content. Application of CA increased seed sodium by $30 \%$, but manganese concentration did not change with any application. The lack of response of seed manganese to the application of chelating agents could be due to low binding constant of manganese with all the chelating agents [23]. However, we cannot explain the high level of manganese in leaves during the flowering stages [32]. In spite of the importance of macro- and micro-elements [13-21] for soybean growth and development, further research is needed to understand the mechanisms controlling the relationships between chelating agents and nutrient uptake by plants and the relationships between chelating agents and nutrient deposition in the seed. Altering the composition of soybean seed with applications of CA, SA,

Table 2. Ratios of $A_{1} / A_{2}$ for various treatments, where $A_{1}=$ Linoleic + Linolenic, $A_{2}=$ Palmitic + Stearic + Oleic, $C=$ Control, $\mathrm{Fe}=\mathrm{FeCl}_{2}, \mathrm{CA}=$ Citric acid, $\mathrm{DA}=$ Disodium EDTA, $\mathrm{SA}=$ Salicylic acid, $\mathrm{CA}+\mathrm{Fe}=\mathrm{Citric}$ acid $+\mathrm{FeCl}_{2}, \mathrm{DA}+$ $\mathrm{Fe}=\mathrm{EDTA}+\mathrm{FeCl}_{2}, \mathrm{SA}+\mathrm{Fe}=$ Salicylic acid $+\mathrm{FeCl}_{2}$.

\begin{tabular}{ccc}
\hline & & $\mathrm{A}_{1} / \mathrm{A}_{2}$ \\
\hline $\mathrm{C}$ & $=(54.4+9.58) /(12.55+4.30+18.75)$ & $=1.79$ \\
$\mathrm{Fe}$ & $=(55.75+7.13) /(11.50+4.4+21.3)$ & $=1.69$ \\
$\mathrm{CA}$ & $=(56.6+6.85) /(11.0+4.33+21.35)$ & $=1.51$ \\
$\mathrm{DA}$ & $=(56.9+6.6) /(10.5+4.4+21.7)$ & $=1.73$ \\
$\mathrm{SA}$ & $=(55.8+9.8) /(13.7+4.5+16.3)$ & $=1.74$ \\
$\mathrm{CA}+\mathrm{Fe}$ & $=(55.5+10.5) /(13.9+4.5+15.6)$ & $=1.90$ \\
$\mathrm{DA}+\mathrm{Fe}$ & $=(52.7+8.9) /(12.5+4.7+22.9)$ & $=1.53$ \\
$\mathrm{SA}+\mathrm{Fe}$ & &
\end{tabular}


Table 3. Macro-elements and trace (micro) elements in soybean as affected by chemical treatments, where, $\mathrm{C}=\mathrm{control}, \mathrm{Fe}=\mathrm{FeCl} 2$, $\mathrm{CA}=$ Citric acid, $\mathrm{DA}=$ Disodium EDTA, $\mathrm{SA}=$ Salicylic acid, $\mathrm{CA}+\mathrm{Fe}=\mathrm{Citric}$ acid $+\mathrm{FeCl}_{2}, \mathrm{DA}+\mathrm{Fe}=\mathrm{Disodium} \mathrm{EDTA}+\mathrm{FeCl}_{2}$, and $\mathrm{SA}+\mathrm{Fe}=$ Salicylic acid $+\mathrm{FeCl}_{2}$.

\begin{tabular}{ccccccc}
\hline Treatments & $\begin{array}{c}\text { Macro elements (\%) } \\
\mathrm{Ca}\end{array}$ & $\mathrm{K}$ & $\mathrm{Mg}$ & $\mathrm{N}$ & $\mathrm{P}$ & $\mathrm{S}$ \\
\hline $\mathrm{C}$ & $0.40 \mathrm{~cd}$ & $2.20 \mathrm{bc}$ & $0.29 \mathrm{c}$ & $5.80 \mathrm{c}$ & $0.78 \mathrm{ab}$ & $0.32 \mathrm{a}$ \\
$\mathrm{Fe}$ & $0.50 \mathrm{a}(+25.0 \%)$ & $2.09 \mathrm{bc}$ & $0.31 \mathrm{a}(7.0 \%)$ & $6.12 \mathrm{~b}(+5.5 \%)$ & $0.78 \mathrm{a}$ & $0.33 \mathrm{a}$ \\
$\mathrm{CA}$ & $0.41 \mathrm{bcd}$ & $2.07 \mathrm{c}$ & $0.30 \mathrm{abc}$ & $6.17 \mathrm{~b}(+6.4 \%)$ & $0.70 \mathrm{~d}(-10.3 \%)$ & $0.32 \mathrm{a}$ \\
$\mathrm{DA}$ & $0.40 \mathrm{~cd}$ & $2.13 \mathrm{bc}$ & $0.29 \mathrm{c}$ & $6.39 \mathrm{a}(+10.0 \%)$ & $0.76 \mathrm{abc}$ & $0.300 \mathrm{~b}$ \\
$\mathrm{SA}$ & $0.38 \mathrm{~d}$ & $2.25 \mathrm{bc}$ & $0.28 \mathrm{c}$ & $6.23 \mathrm{ab}(+7.4 \%)$ & $0.73 \mathrm{bcd}$ & $0.28 \mathrm{c}(-12.5 \%)$ \\
$\mathrm{CA}+\mathrm{Fe}$ & $0.43 \mathrm{bc}$ & $2.70 \mathrm{a}(+23.0 \%)$ & $0.31 \mathrm{ab}(+7.0 \%)$ & $6.15 \mathrm{~b}(+6.0 \%)$ & $0.81 \mathrm{a}$ & $0.27 \mathrm{c}(-15.6 \%)$ \\
$\mathrm{DA}+\mathrm{Fe}$ & $0.42 \mathrm{bc}$ & $2.22 \mathrm{bc}$ & $0.29 \mathrm{bc}$ & $5.79 \mathrm{c}$ & $0.74 \mathrm{bcd}$ & $0.30 \mathrm{~b}(-6.0 \%)$ \\
$\mathrm{SA}+\mathrm{Fe}$ & $0.38 \mathrm{~d}$ & $2.18 \mathrm{bc}$ & $0.26 \mathrm{~d}(-6.3 \%)$ & $5.8 \mathrm{c}$ & $0.72 \mathrm{~cd}(-7.7 \%)$ & $0.32 \mathrm{a}$ \\
\hline
\end{tabular}

Treatments Trace elements (mg/kg)

\begin{tabular}{cccccccc} 
& $\mathrm{B}$ & $\mathrm{Cu}$ & $\mathrm{Fe}$ & $\mathrm{Mn}$ & $\mathrm{Mo}$ & $\mathrm{Na}$ & $\mathrm{Zn}$ \\
\hline $\mathrm{C}$ & $38.20 \mathrm{c}$ & $9.14 \mathrm{e}$ & $82.43 \mathrm{~cd}$ & $63.23 \mathrm{abc}$ & $11.54 \mathrm{~b}$ & $457.4 \mathrm{bc}$ & $62.13 \mathrm{c}$ \\
$\mathrm{Fe}$ & $44.40 \mathrm{a}(+16.0 \%)$ & $9.79 \mathrm{~d}(+7.0 \%)$ & $93.98 \mathrm{~b}(+14.0 \%)$ & $64.44 \mathrm{ab}$ & $13.95 \mathrm{~b}$ & $330.2 \mathrm{c}$ & $70.95 \mathrm{~b}(+14.0 \%)$ \\
$\mathrm{CA}$ & $41.95 \mathrm{~b}(+11.0 \%)$ & $10.69 \mathrm{c}(+17.0 \%)$ & $108.3 \mathrm{a}(+31.0 \%)$ & $61.72 \mathrm{bc}$ & $11.37 \mathrm{~b}$ & $594.4 \mathrm{a}(+30.0 \%)$ & $71.44 \mathrm{~b}(+15.0 \%)$ \\
$\mathrm{DA}$ & $38.60 \mathrm{c}$ & $13.69 \mathrm{a}(+50.0 \%)$ & $81.13 \mathrm{~cd}$ & $67.2 \mathrm{bc}$ & $18.16 \mathrm{a}(+57.0 \%)$ & $493.0 \mathrm{ab}$ & $79.9 \mathrm{a}(+28.0 \%)$ \\
$\mathrm{SA}$ & $42.53 \mathrm{~b}(+11.0 \%)$ & $11.38 \mathrm{~b}(+24.5 \%)$ & $73.83 \mathrm{e}(-10.4 \%)$ & $61.9 \mathrm{bc}$ & $13.62 \mathrm{~b}$ & $389.0 \mathrm{bc}$ & $63.18 \mathrm{c}$ \\
$\mathrm{CA}+\mathrm{Fe}$ & $42.31 \mathrm{~b}(+11.0 \%)$ & $11.34 \mathrm{~b}(+24.0 \%)$ & $77.93 \mathrm{de}$ & $56.6 \mathrm{c}$ & $13.06 \mathrm{~b}$ & $406.7 \mathrm{bc}$ & $64.34 \mathrm{c}$ \\
$\mathrm{DA}+\mathrm{Fe}$ & $39.67 \mathrm{c}$ & $10.01 \mathrm{~d}(+9.6 \%)$ & $86.35 \mathrm{c}$ & $68.64 \mathrm{a}$ & $13.62 \mathrm{~b}$ & $408.9 \mathrm{bc}$ & $69.5 \mathrm{~b}(12.0 \%)$ \\
$\mathrm{SA}+\mathrm{Fe}$ & $39.00 \mathrm{c}$ & $10.31 \mathrm{~cd}(+13.0 \%)$ & $82.35 \mathrm{~cd}$ & $69.24 \mathrm{a}$ & $17.33 \mathrm{a}(+50.0 \%)$ & $366.7 \mathrm{bc}$ & $68.83 \mathrm{~b}(11.0 \%)$ \\
\hline
\end{tabular}

*Means given within a column with the same letter are not significantly different at $\mathrm{p} \leq 0.05$. Four replicates were used. The numbers in the brackets with $\%$ are increase $(+)$ or decrease $(-)$ from the control for a given seed composition constituents.

Table 4. Chemical and physical characteristics of soil.

\begin{tabular}{cc}
\hline Soil & Chemical and physical properties of soil \\
\hline Soil texture & Sandy clay \\
Base saturation & 95.1 \\
pH $\left(\mathrm{CaCl}_{2}\right)$ & 5.70 \\
Equivalent water $\mathrm{pH}$ & 6.30 \\
Organic matter (OM \%) & 36.9 \\
Macro-elements (\%) & \\
$\mathrm{N}$ & 2.11 \\
$\mathrm{~S}$ & 0.17 \\
$\mathrm{P}$ & 0.02 \\
$\mathrm{Ca}$ & 3.30 \\
$\mathrm{~K}$ & 0.35 \\
$\mathrm{Mg}$ & 0.21 \\
$\mathrm{Cu}$ & \\
$\mathrm{Fe}$ & 0.50 \\
$\mathrm{Mn}$ & 65.0 \\
$\mathrm{Mo}$ & 84.0 \\
$\mathrm{Zn}$ & 0.10 \\
$\mathrm{Na}$ & 6.50 \\
$\mathrm{~B}$ & 81.0 \\
\hline
\end{tabular}


Table 5. Stability constants of EDTA, citric acid, and salicylic acid with elements [23].

\begin{tabular}{cccccccc}
\hline Chelating agent & $\mathrm{Ca}$ & $\mathrm{Mg}$ & $\mathrm{Mn}$ & $\mathrm{Fe}^{2+}$ & $\mathrm{Fe}^{3+}$ & $\mathrm{Zn}$ & $\mathrm{Cu}$ \\
\hline EDTA & 10.7 & 8.69 & 13.56 & 14.3 & 25.70 & 16.5 & 18.8 \\
Citric acid & 3.50 & 2.80 & 3.20 & 3.20 & 11.85 & 4.50 & 6.10 \\
Salicylic acid & N/A & 4.70 & 2.70 & 6.55 & 16.35 & 6.85 & 10.6 \\
\hline
\end{tabular}

*Not available.

and ferrous ion will further expand our knowledge about the role of chelating agents in seed constituents quality.

\section{CONCLUSION}

The application of CA and SA increased seed protein by $2.9 \%$ and $3.4 \%$, decreased palmitic acid by $14.3 \%$ and $16.7 \%$, decreased linolenic by $17.7 \%$ and $31.3 \%$, and increased oleic acid by $33.0 \%$ and $15.4 \%$, respectively for CA and SA. All seven treatments (Table 1) altered the seed composition of all macro- and micro-elements, except manganese. Further research is needed before conclusive observations are made.

\section{ACKNOWLEDGEMENTS}

This research was supported in part by USDA/FSR and NSF grant, and an HBCU-UP grant from MVSU. We would like to thank Sandra Mosley for soybean seed protein, oil, and fatty acid analyses. We would like to thank Dr Nacer Bellaloui, one of the co-authors, for supporting us with lab facilities and SAS analysis at USDA-ARS, Crop Genetics Research Unit, Stoneville, MS. First author would like to thank his two daughters, Neeta M. Goli and Vidya Ford for reviewing the manuscript, his colleague from Mathematics Department, Dr. Xiaoqin P. Wu for reference management list and for figures formatting.

\section{REFERENCES}

[1] Ash, M., Livezey, J. and Dohlman, E. (2006) Soybean backgrounder. Electronic Outlook Report from the Economic Research Service, USDA.

http://www.ers.usda.gov/publications/OCS/apr06/OCS20 0601/OCS20060 1 lowres.pdf

[2] Brumm, T.J. (1994) Improving quality in soybeans-IQS. Soybean Research \& Development Council, Illinois Soybean Association.

http://soybean.uwex.edu/library/soybean/forage/Yield an d Quality/ESTIMATING THE VALUE_OF_PROTEIN AND OIL IN SOYBEANS.htm

[3] Kassem, M.A., Meksem, K., Iqbal, M., Njiti, V.N., Banz, W.J., Winters, T.A., Wood, A. and Lightfoot, D.A. (2004) Definition of soybean genomic regions that control seed phytoestrogen amounts. Journal of Biomedicine and Biotechnology, 1, 52-60. doi:10.1155/S1110724304304018

[4] Capeleti, I., Ferrarese, M.L.L., Krzyzanowski, F.C. and Ferrarese, F.O. (2005) A new procedure for quantification of lignin in soybean (Glycine max (L.) Merrill) seed coat and their relationship with the resistance to mechanical damage. Seed Science and Technology, 33, 511-515. http://www.ingentaconnect.com/content/ista/sst/2005/000 00033/00000002/art00025

[5] United States Department of Agriculture. (2011) Oil seeds, world markets and trade. http://www.fas.usda.gov/oilseeds/circular/2011/March/oil seeds.pdf

[6] Harwood, J.L. (2010) Plant lipid biochemistry, plant fatty acid synthesis. AOCS Lipid Library. http://lipidlibrary.aocs.org/plantbio/fa biosynth/index.ht $\underline{\mathrm{m}}$

[7] Dutton, H.J., Lancaster, C.J., Evans, C.D., and Cowan, J.C. (1951) The flavor problem of soybean oil. VIII. Linolenic acid. Journal of the American Oil Chemists' Society, 28, 115-118. doi:10.1007/BF02612206

[8] Dutton, H.J. and Cowan, J.C. (1949-1950) The flavor problem of soybean oil. 1950-1951 year book of agriculture. International Green Book, 575-578. http://naldc.nal.usda.gov/download/IND43894125/PDF

[9] Simons, J.N., Swindler, R. and Benedict, H.M. (1961) Absorption of chelated iron by soybean roots in nutrient solutions. Physiology, 37, 460-466.

http://www.ncbi.nlm.nih.gov/pmc/articles/PMC549816/p df/plntphys00427-0008.pdf

[10] Hasegawa, H., Rahman, M.A., Saitou, K., Kobayashi, M. and Okumura, C. (2011) Influences of chelating agents on bioavailability and mobility of iron in plant growth media and their effect on radish growth. Environmental and EXperimental, 71, 345-351. doi:10.1016/j.envexpbot.2011.01.004

[11] Christ, R.A. (1974) Iron requirement and iron uptake from various iron compounds by different plant species. Plant physiology, 54, 582-585. doi:10.1104/pp.54.4.582

[12] Wallace, A. and Wallace, G.A. (1992) Some of the problems concerning iron nutrition of plants after four decades of synthetic chelating agents. Journal of Plant $\mathrm{Nu}$ trition, 15, 1487-1508. doi:10.1080/01904169209364416

[13] Vahedi, A. (2012) The Appraisal of micronutrient impact on absorption of macro- and micro-nutrients in Tellar cultivar of soybean. International Journal of Biology, 4, 120-128. doi:10.5539/ijb.v4n1p120

[14] Cakmak, I., Pfeiffer, W.H. and McClafferty, B. (2010) Biofortification of durum wheat with zinc and iron. Cereal Chemistry, 87, 10-20. doi:10.1094/CCHEM-87-1-0010

[15] Berglund D.R. and Helms, T.C. (2003) Soybean production. http://www.ag.ndsu.edu/pubs/plantsci/rowcrops/a250w.ht $\underline{\mathrm{m}}$

[16] Smith, D. (2010) Micronutrients can have a macro impact. 
Farm Journal, 134, 27-30.

[17] Randall, G.W., Schulte, E.E. and Corey, R.B. (1974) Effect of soil and foliar-applied manganese on the micronutrient content and yield of soybeans. Agronomy Journal, 67, 502-507. doi:10.2134/agronj1975.00021962006700040012x

[18] Heitholt, J.J., Sloan, J.J. and MacKown, C.T. (2002) Copper, manganese and zinc fertilization effects on growth of soybean on a calcareous soil. Journal of Plant Nutrition, 25, 1727-1740. doi:10.1081/PLN-120006054

[19] Martens, D.C. and Westermann, D.T. (1991) Fertilizer applications for correcting micronutrient deficiencies. Soil Science Society of America, 549-553. http://eprints.nwisrl.ars.usda.gov/777/1/753.pdf

[20] Piccolo, A., Pietramellara, G. and Celan, G. (1993) Iron extractability from iron-humate complexes by a siderophore and a mixture of organic acids. Canadian Journal of Soil Sciences, 73, 293-298. doi:10.4141/cjss93-031

[21] Chereskin, B.M. and Castelfranco, P.A. (1982) Effects of iron and oxygen on chlorophyll synthesis II. Observations on the biosynthetic pathway in isolated etiochloroplasts. Plant Physiology, 69, 112-116. doi:10.1104/pp.69.1.112

[22] Bledsoe, O., Goli, M., Pande, M. and Mahone, W. (2008) Effect of various chelating agents on the chemical uptake into lemon grass. Mississippi Academy of Sciences Meeting, 53, 29.

http://msacad.org/journal/jan08journal/jan08.pdf

[23] Eby, G. (2006) Stability constants $\left(\log \mathrm{K}_{1}\right)$ of various metal chelates. Chapter 6 - Sequestrants in foods. CRC Handbook of Food Additives. http://www.coldcure.com/html/stability_constants.html

[24] Bellaloui, N., Reddy, K.N., Zablotowicz, R.M. and Men- gistu, A. (2006) Simulated glyphosate drift influences nitrate assimilation and nitrogen fixation in nonglyphosateresistant soybean. Journal of Agriculture and Food Chemistry, 54, 3357-3364. doi:10.1021/jf0531981

[25] Bellaloui, N. and Gillen, A.M. (2010) Soybean seed protein, oil, fatty acids and mineral composition as influenced by soybean corn rotation. Agricultural Sciences, 1, 27-30. doi:10.4236/as.2010.13013

[26] Helrich, K. (1990a) Method 988.05. Official Methods of Analysis. 15th Edition, The Association of Official Analytical Chemists Inc., Arlington.

[27] Helrich, K. (1990b) Method 920.39. Official Methods of Analysis. 15th Edition, The Association of Official Analytical Chemists Inc., Arlington.

[28] Soil, water and plant analysis. University of Georgia, Athens. http://swpa.uga.edu/index.php?/site/capabilities/

[29] SAS. (2001) SAS 9.1 TS level 1M3, Windows version. 5.1.2600. SAS Institute, Gary.

[30] Advanced chemistry development software (freeware). http://www.acdlabs.com/resources/freeware/chemsketch/

[31] Brown, J.C., Tiffin, L.O. and Holmes, R.S. (1960) Competition between chelating agents and roots as factor affecting absorption of Iron and other ions by plant species. Plant Physiology, 35, 878-886. doi:10.1104/pp.35.6.878

[32] Stanton, M., Spann, T., Pande, M. and Goli, M. (2011) Qualitative and quantitative distribution of trace elements found in the leaves of the soybean plants that were exposed to chelating agents and ferrous ion. Mississippi Academy of Sciences meeting, 75, 31. http://msacad.org/journal/jan11journal/mas11a.pdf 